\title{
Suppression of Insulin Secretion by Protein Deprivation in Obesity
}

\author{
D. E. Schteingart, A. K. McKenzie, R. S. Victoria, and H. S. Tsao
}

The effect of low protein diets on insulin levels was studied in 17 obese, nondiabetic hyperinsulinemic subjects. Their mean weight was $271 \%$ of ideal weight. Nine patients were fed a weight-maintaining 3700-calorie diet for 14 days; this diet contained 398 $g$ carbohydrate and $170 \mathrm{~g}$ protein. The patients were then fed an isocaloric diet containing only $6 \mathrm{~g}$ protein and $587 \mathrm{~g}$ carbohydrate for 14 more days. Mean basal insulin levels decreased from 50.4 to 34.7 $\mu \mathrm{U} / \mathrm{ml}$. This decrease was accompanied by a significant decrease in mean plasma glucose. In seven patients who were fed the low-protein diet after a 4-day period of total fast, the low-protein diet prevented the recovery of basal insulin levels decreased during fasting. These findings were in contrast to the apparent recovery of basal insulin levels observed when the control rather than the low-protein diet was refed in 4 patients following a fast. The suppression of basal insulin levels by protein deprivation was not correlated with changes in plasma glucose, glucagon, urinary 17-hydroxycorticoids, or body woight. Although urinary 17-hydroxycorticoids and free cortisol decreased significantly on protein-restricted diets, treatment with cortisol did not prevent the effect of protein deprivation on basal insulin and glucose levels. Plasma levels of branched chain amino acids (valine, leucine, and isoleucine) decreased in parallel to insulin levels on the isocaloric low-protein diets. We conclude that protein-restricted diets can decrease basal plasma insulin levels in obesity even in the presence of sufficient calories to maintain weight and high carbohydrate content. Of the factors investigated that may account for this phenomenon, it is unlikely that glucagon, glucose, or cortisol play a direct role. It is possible that protein as well as carbohydrate plays a role in the development of hyperinsulinemia and insulin resistance in obesity.

$\mathbf{H}^{\mathrm{r}}$ YPERINSULINEMIA, decreased sensitivity of peripheral tissues to both exogenous and endogenous insulin and abnormalities of glucose tolerance are frequent findings in obesity. ${ }^{1.2}$ These abnormalities are reversed by dietary deprivation and weight reduction ${ }^{3-5}$ and induced in normal subjects made obese by overfeeding. ${ }^{\circ}$ The role of specific nutrients in the hyperinsulinemia of obese people has not been clearly defined. Studies by Grey and Kipnis ${ }^{7}$ suggest that diets high in carbohydrate are associated with hyperinsulinemia whereas isocaloric diets low in carbohydrate decrease circulating insulin levels. In contrast to these observations,
Bierman $^{8}$ and Brunzell et al. ${ }^{9}$ reported that high carbohydrate diets given to normal subjects or mildly diabetic patients decrease basal and glucose-stimulated insulin levels and improve glucose tolerance. The role of dietary protein in the hyperinsulinemia of human obesity has not been reported.

The present study investigates the effect of low-protein diets on insulin levels in obesity. The results suggest that protein deprivation, even in the presence of high calorie and carbohydrate intake, suppresses basal insulin levels.

\section{MATERIALS AND METHODS}

Scventcen obese, nondiabctic, hyperinsulinemic subjects were studied. Twelve were male and five were female; their mean age was $30.9 \pm 2.1 \mathrm{yr}$ (mean $\pm \mathrm{SE}$ ), and their mean weight was $271 \pm 12.4 \%$ of ideal weight. On a weightmaintaining mixed diet, mean basal glucose levels were normal, $96.6 \pm 3.8 \mathrm{mg} / \mathrm{dl}$, but mean basal insulin levels $(57.8$ $\pm 5.3 \mu \mathrm{U} / \mathrm{dl})$ and mean insulin/glucose $(\mathrm{I} / \mathrm{G})$ ratio, $(0.59 \pm$ 0.05 ) were high. These levels were in contrast to those obtained in 235 nonobese, nondiabetic subjects whose values were $93.7 \pm 0.96,8.15 \pm 0.58$, and $0.086 \pm 0.005$, respectively.

Studies were performed according to the following general protocol: Patients were admitted to the Clinical Research Center for the duration of the study; they were kept under strictly supervised conditions and although they were ambulatory, their activities were restricted to the metabolic unit. They were initially placed on a control diet. The caloric content of this diet was sufficient to maintain body weight as established during a preliminary period of observation. The diet consisted of food of mixed composition, providing $50 \%$ of the calories as carbohydrate and $20 \%$ as protein. The carbohydrate was given in the form of equal proportions of simple and complex sugars. Once a weight maintenance level had been established, the diet was fed for a total of 14 days. The control diet was then followed by: (1) a total fast for 4 days,

From the Department of Internal Medicine, Division of Endocrinology and Metabolism and the Metabolism Research Unit, The University of Michigan. Ann Arbor, Mich.

Received for publication November 17, 1978.

Supported in part by USPHS Grants AM-02244, 5$M O 1-R R-4216$, and TI-AM-05001.

Address reprint requests to D. E. Schteingart, M.D., University of Michigan Hospital. Room S3450, Ann Arbor, Mich. 48109.

(c) 1979 by Grune \& Stratton, Inc.

0026-0495/79/2809 0010\$01.00/0 
during which only calorie-free liquids were allowed; and (2) an experimental protein-restricted diet as described below for 14 days. In some cases, the fast was followed by either the control diet or the protein-restricted diet for periods of 14 days each.

Plasma insulin, glucose, glucagon, cortisol, amino-acid levels, urinary 17-hydroxycorticoids (17-OHCS), and free cortisol were measured at the end of each diet or on the last day of the total fast. Plasma insulin, ${ }^{10}$ glucagon, ${ }^{11}$ and cortisol $^{12}$ and urinary free cortisol were measured by radioimmunoassay, plasma glucose by autoanalyzer, ${ }^{14}$ urinary 17 OHCS by the method of Silber and Porter, ${ }^{14}$ and plasma amino acid levels by a Beckman amino acid analyzer. The data was analyzed for statistical significance by a Student's $t$ test. Values are expressed as mean $\pm \mathrm{SE}$.

The insulin/glucose $(I / G)$ ratio is used in this study as an expression of the relationship between insulin and glucose and its relative change during the administration of the various experimental diets.

\section{RESULTS}

The well-known decrease in plasma insulin levels observed in obese people during total fast is illustrated in Fig. 1. Seven obese subjects were studied on a weight-maintaining, 3300-calorie, mixed diet for 14 days; they were subsequently fasted for 4 days. There was a significant fall in plasma insulin and glucose and the $I / G$ ratio at the end of the fast.

As shown in Fig. 2, a suppressive effect qualitatively similar to that produced by total fast was also observed with diets deficient in protein but

$\begin{array}{lll}\text { CALORIES } & 3328 & 0 \\ \text { CARBOHYORATE (GN) } & 345 & 0 \\ \text { PROTEIN (GN) } & 147 & 0 \\ \text { DURATION (DAYS) } & 14 & 4\end{array}$
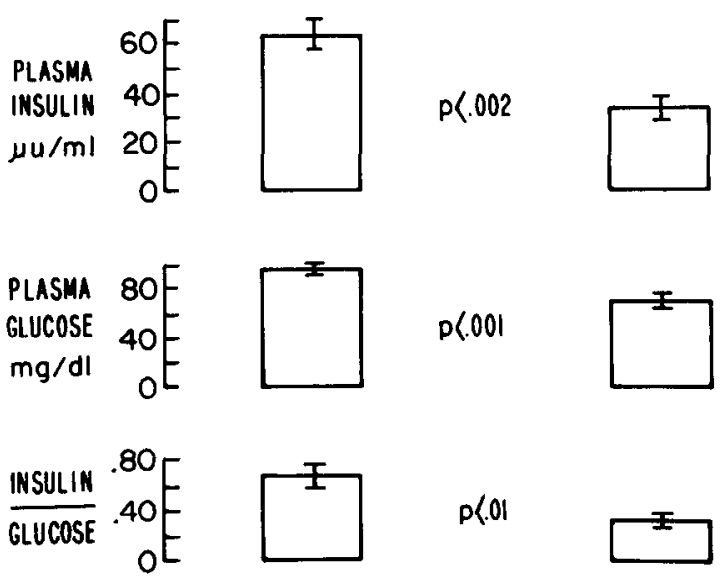

Fig. 1. Suppression of basal plasma insulin, glucose, and $\mathrm{I} / \mathrm{G}$ ratio by total fast in seven obese, nondiabetic patients.

$\begin{array}{lcc}\text { CALORIES } & 3711 & 3711 \\ \text { CARBOHYORATE (6N) } & 398 & 587 \\ \text { PROTEIN (GN) } & 170 & 5.9 \\ \text { OURATION (DAYS) } & 14 & 14\end{array}$
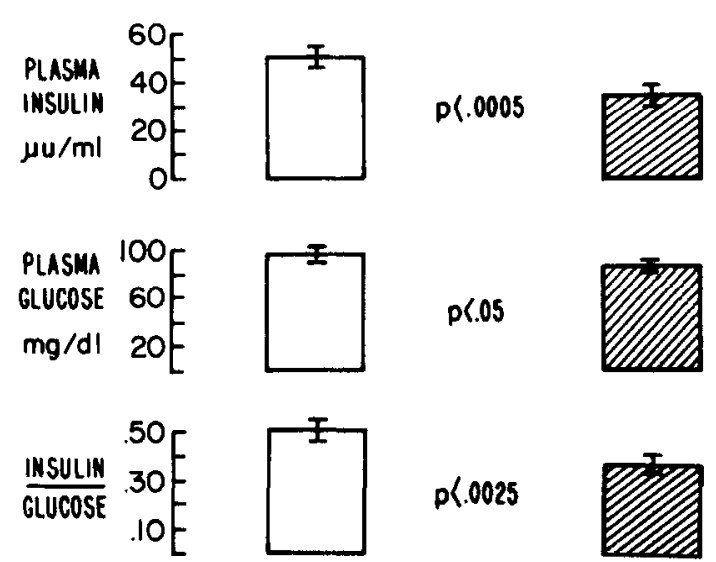

Fig. 2. Suppression of basal plasma insulin, glucose. and $\mathrm{I} / \mathrm{G}$ ratio by low-protein diets in nine obese, nondiabetic patients.

adequate in calories to maintain weight. Nine obese patients were fed a weight-maintaining, 3700-calorie diet for 14 days. This diet contained $398 \mathrm{~g}$ carbohydrate and $170 \mathrm{~g}$ protein. The patients were then fed an isocaloric diet containing only $6 \mathrm{~g}$ protein for 14 more days. This diet contained $587 \mathrm{~g}$ carbohydrate.

Protein restriction caused a significant decrease in mean basal insulin levels, from 50.4 to $34.7 \mu \mathrm{U} / \mathrm{ml}$. This decrease was accompanied by a modest but significant decrease in the mean plasma glucose level from 96 to $87 \mathrm{mg} / \mathrm{dl}$ and in the mean $\mathrm{I} / \mathrm{G}$ ratio from 0.51 to 0.39 .

To rule out the possibility that the decrease in insulin levels observed with protein restriction was due to the concomitant increase in carbohydrate intake as previously reported ${ }^{8,9}$ four obese subjects were fed a weight-maintaining, 3500calorie diet for 28 days. This diet contained 130 $\mathrm{g}$ protein. For the first 14 days, the carbohydrate content was $437 \mathrm{~g}$; for the last 14 days, $612 \mathrm{~g}$. As shown in Fig. 3, there was little suppression of plasma insulin or glucose when the high-carbohydrate diet was fed without restriction of protein.

As shown in Fig. 4, less-severe restriction of dietary protein can also result in a decrease in basal insulin levels. Two obese patients were fed a weight-maintaining diet for 14 days. This diet contained 144 and $120 \mathrm{~g}$ protein, respectively. 


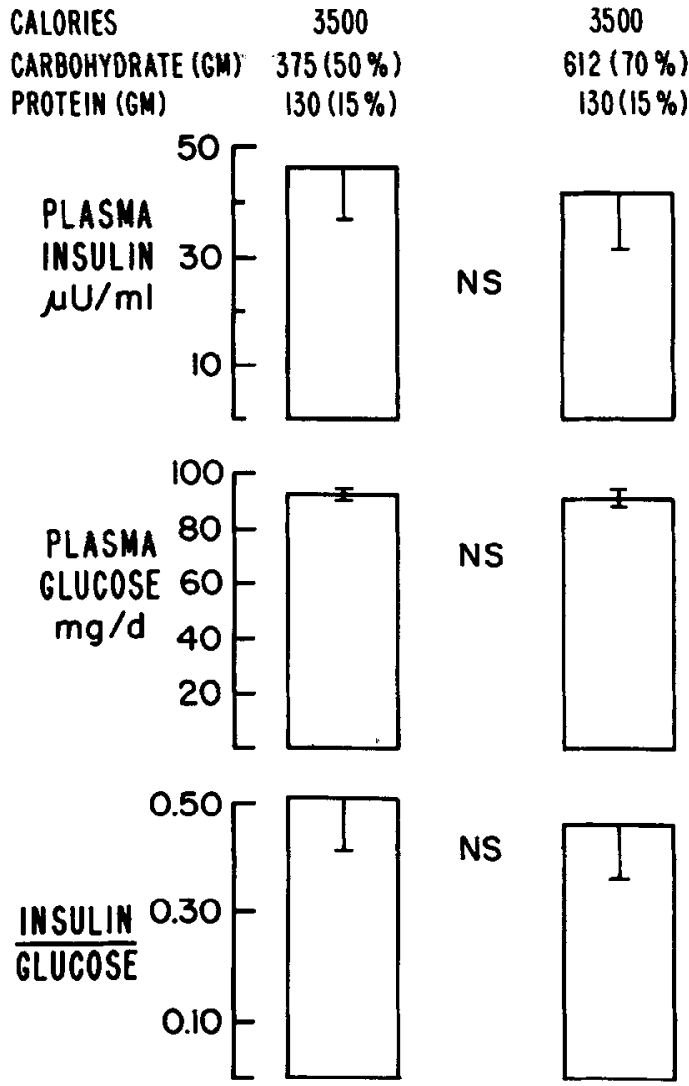

Fig. 3. Lack of suppression of basal plasma insulin when high-carbohydrate diets are fed without restriction of protein.

They were then fed an isocaloric diet containing only $20 \mathrm{~g}$ protein for 20 days. Mean basal plasma insulin levels decreased on the low-protcin diet. However, mean basal plasma glucose did not change.

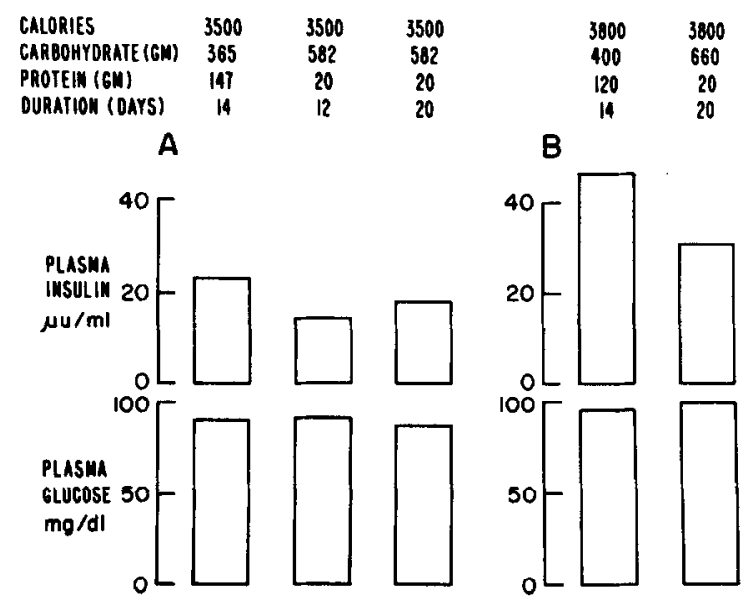

Fig. 4. Suppression of plasma insulin levels by moderately $(20 \mathrm{~g})$ protein-restricted diets, in 2 obese petients.
As shown in Fig. 5, protein restriction can also prevent the recovery with refeeding of plasma insulin levels suppressed by total fast. Seven patients were fed a weight-maintaining, 3300calorie diet for 14 days. This diet contained 345 $\mathrm{g}$ carbohydrate and $147 \mathrm{~g}$ protein. They then fasted for 4 days. The fast was followed by a 3300 -calorie diet containing only $6 \mathrm{~g}$ protein for 14 days. There was a significant decrease in values during fasting, but no significant recovery occurred during the low-protein diet, despite the fact that the carbohydrate content of this diet, $582 \mathrm{~g}$, was higher than the control diet.

These findings are in contrast to the apparent recovery of basal insulin levels observed when the control, rather than the low-protein diet, is refed following a fast. Figure 6 shows this effect clearly demonstrated in four patients during sequential feeding and fasting periods. Insulin and glucose values decreased during each fasting period, recovered with refeeding of the control diet, but remained suppressed on the low-protein diet.

Several studies were performed in order to elucidate the mechanism(s) by which protein restriction decreased basal insulin levels in the obese subjects. Protein restriction might have directly suppressed $\beta$-cell function. Alternatively, factors that are known to influence insulin secretion and are abnormal in obesity might have been affected by protein restriction and caused the lowered basal insulin levels. Changes

\begin{tabular}{|c|c|c|c|}
\hline $\begin{array}{l}\text { CALORIES } \\
\text { CAREOHYORATE (CN) } \\
\text { PROTEIN (CN) } \\
\text { OURATION (DAYS) }\end{array}$ & $\begin{array}{c}3322 \\
345 \\
147 \\
14\end{array}$ & $\begin{array}{l}0 \\
0 \\
0 \\
4\end{array}$ & $\begin{array}{l}3320 \\
502 \\
70 \\
14\end{array}$ \\
\hline
\end{tabular}

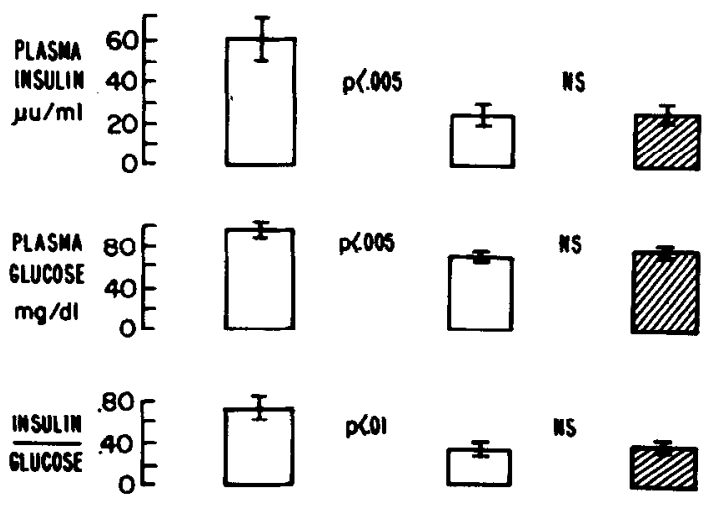

Fig. 5. Suppression of plasma insulin, glucose, and I/G ratio by fasting in seven obese, nondiabetic subjects. Lack of recovery with low protein diets. 


$\begin{array}{lccccc}\text { CALORIES } & 4000 & 0 & 4000 & 0 & 4000 \\ \text { CARBOHYORATE (GM) } & 400 & 0 & 400 & 0 & 650 \\ \text { PROTEIN (GM) } & 200 & 0 & 200 & 0 & 6 \\ \text { DURATION (DAYS) } & 14 & 4 & 14 & 4 & 14\end{array}$
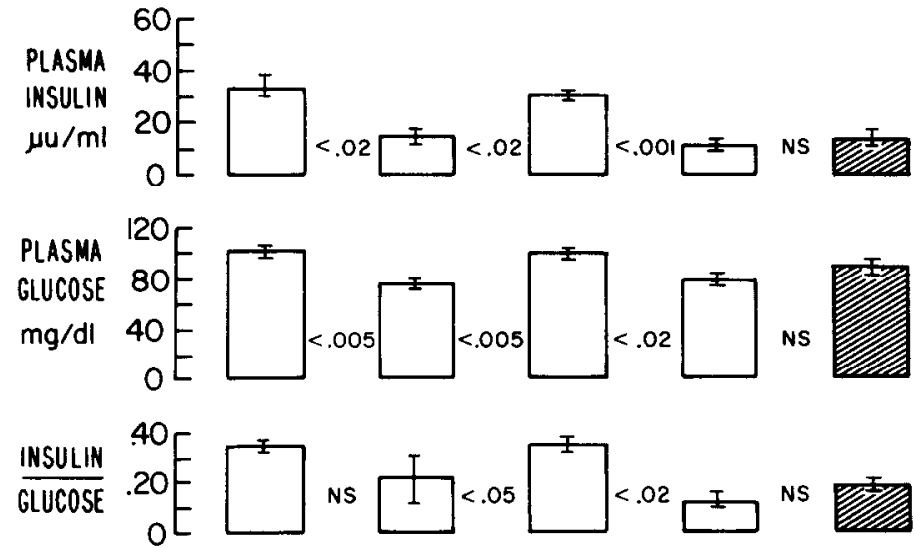

Fig. 6. Sequential responses to fasting and low-protein diets of four obese, nondiabetic patients.

in plasma glucose, glucagon, cortisol, amino acids, and body weight were measured among these factors. There was lack of correlation between changes in basal plasma insulin levels and changes in plasma glucose (correlation coefficient 0.2426$)$, glucagon $(0.4221)$, urinary 17 OHCS 0.0822), and body weight (0.0846) during protein deprivation. Plasma glucagon levels changed inconsistently on the isocaloric low-protein diets. The change ranged from a decrease of $25 \%$ to an increase of $100 \%$.
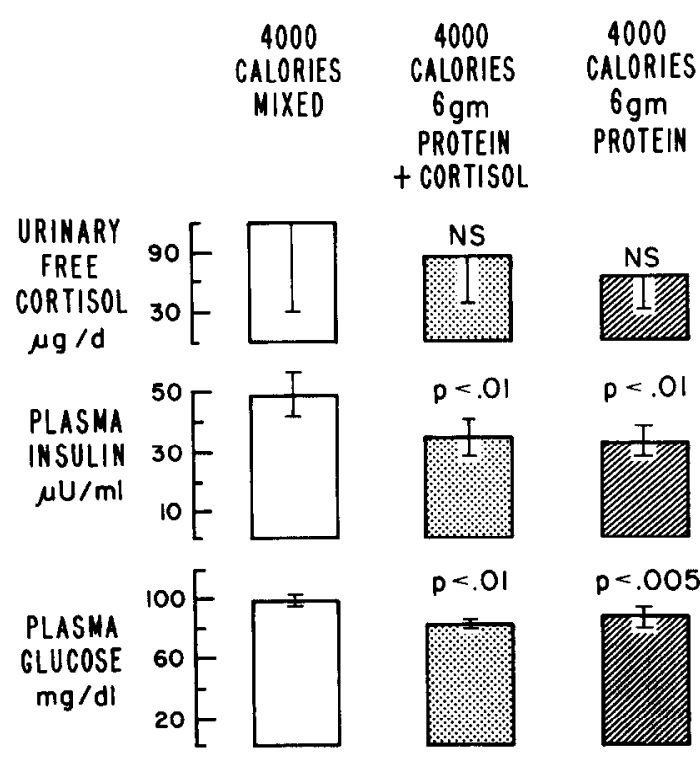

Fig. 7. Failure of cortisol treatment to prevent the suppression of plasma insulin by low-protein diets in five obese patients.
Urinary 17-OHCS and free cortisol decreased significantly on protein-restricted diets; urinary 17-OHCS from a mean value of $12.0 \pm 1.6$ to $8.6 \pm 1.0 \mathrm{mg} / \mathrm{d}(p<0.005)$, and urinary free cortisol from a mean value of $100 \pm 30$ to $63 \pm$ $10.6 \mu \mathrm{g} / \mathrm{d},(p<0.01), n=8$. However, as shown in Fig. 7, the administration of cortisol during isocaloric low-protein diets in doses equivalent to basal cortisol secretion rates did not prevent the decrease in basal insulin and glucose levels induced by the low-protein diet.

The plasma levels of the branched chain amino acids valine, leucine, and isoleucine decreased in parallel to insulin levels on the isocaloric low-protein diet. Valine decreased from a mean value of $318.9 \pm 33.8$ to $161.3 \pm 23$ $\mathrm{nm} / \mathrm{ml}(p<0.005)$, leucine from $152.2 \pm 24.0$ to $77.8 \pm 15.4 \mathrm{~nm} / \mathrm{ml}(p<0.05)$, and isoleucine from $84.3 \pm 13.8$ to $50.4 \pm 8.5 \mathrm{~nm} / \mathrm{ml}(p<$ $0.025), N=4$. Levels returned to control values when the control diet was refed.

\section{DISCUSSION}

It is clear from these and previously published studies $^{6,15,16}$ that diet plays an important role in the hyperinsulinemia and associated abnormalities of glucose tolerance frequently observed in obesity. It has been postulated that increased food intake in obesity leads to overstimulation of $\beta$-cell function and hyperinsulinemia that can be detected both in the basal state and in response to insulin secretagogues. Concomitant with the 
rise in plasma insulin levels, there occurs a decrease in peripheral sensitivity to insulin and, frequently, abnormalities of glucose metabolism. The abnormalities in insulin secretion and glucose tolerance observed in obesity are reversed by dietary deprivation and weight reduction. In addition, Sims et $a .^{6}$ have been able to induce these abnormalities in normal subjects who are made obese by overfeeding. Studies by Grey and Kipnis ${ }^{7}$ suggest that diets high in carbohydrate (65\% of calories) are associated with hyperinsulinemia while isocaloric diets low in carbohydrate (25\% of calories) decrease circulating insulin levels. These authors postulated that high carbohydrate ingestion provides greater stimulation of pancreatic $\beta$-cell function in the obese as compared to the nonobese subject. In contrast with these observations, Bierman $^{8}$ and Brunzell et al. ${ }^{9}$ reported that highcarbohydrate diets ( $85 \%$ of calories) given to normal subjects and mildly diabetic patients (1) decrease fasting blood glucose, (2) improve glucose tolerance, (3) decrease basal and glucosc-stimulated insulin levcls, and (4) improve peripheral sensitivity to insulin. The type of carbohydrate fed may also affect insulin levels. The insulin response to glucose of the isolated perfused pancreas was much greater when rats were fed a high-sucrose rather than a high-starch diet for several weeks prior to sacrifice. ${ }^{17}$ The role of various types of carbohydrates (sucrose versus starches) in the modulation of insulin secretion and glucose metabolism in obese people has not been defined.

The data reported here demonstrates that protein restriction per se without restriction of calories or carbohydrate can also lower the high insulin levels found in obese people. In fact, these changes occurred in the presence of high carbohydrate intake that had been postulated to stimulate insulin secretion.

The mechanism by which protein deprivation lowers plasma insulin levels remains to be defined. Like and Chick $^{18}$ demonstrated a significant decrease in the $\beta$-cell mitotic activity of mice with hereditary diabetes fed diets low in protein but high in carbohydrate. Similarly, in the experiments reported here in obese subjects, protein deficiency may have suppressed insulin secretion by a direct effect on $\beta$-cell function.

Alternatively, protein deficiency could have decreased plasma insulin levels by modifying other factors believed to be involved in the pathogenesis of the hyperinsulinemia and peripheral insulin resistance found in obese people. A direct correlation between plasma insulin levcls and adipose cell size has been found in obese subjects. ${ }^{19}$ In addition, decreased intracellular glucose metabolism has been found in large adipocytes. ${ }^{20,21}$ Food deprivation may decrease insulin levels by reducing the size of adipocytes. However, it is unlikely that a decrease in fat cell size occurred in our subjects during isocaloric low-protein diets, accounting for the changes observed in basal insulin levels. Although we have not measured fat cell size, total body weight remained constant for the duration of the isocaloric diets.

A lack of direct correlation between changes in basal insulin and plasma glucose or glucagon tends to rule out a primary change in these two factors as the mechanism involved during protein restriction. Instead, it is likely that a decrease in plasma insulin secondarily improved peripheral insulin sensitivity and lowered plasma glucose. Archer ct al. ${ }^{22}$ have reported that circulating peripheral lymphocytes obtained from obese subjects bind less insulin than those from normal subjects. DeMeyts et al. ${ }^{23}$ and Gavin et al. ${ }^{24}$ have demonstrated that the number of available insulin receptors is decreased by increased concentrations of insulin. Thus, in our obese hyperinsulinemic patients, a reduction in insulin secretion by diet could have secondarily increased the number of insulin receptors and enhanced peripheral insulin sensitivity. This could explain the decrease in the $I / G$ ratio observed in our study. Although this ratio is affected by changes in the number and affinity of insulin receptors, it is also influenced by other factors that can independently influence glucose fluxes and insulin secretion.

Urinary 17-OHCS and cortisol secretion rates are found to be increased in $30 \%-50 \%$ of obese people. ${ }^{25}$ Concomitant with this increase are normal plasma cortisol levels; their circadian rhythm is preserved and they respond normally to suppression with dexamethasone. It is possible that excessive cortisol secretion contributes to the hyperinsulinemia and insulin resistance observed in obesity. Vague et al. ${ }^{26}$ reported that a better positive correlation exists between insulin and urinary 17-OHCS than between insulin and either weight or excess weight. Simi- 
larly, a positive correlation exists between urinary $17-\mathrm{OHCS}$ and the $\mathrm{I} / \mathrm{G}$ ratio in nondiabetic obese patients. Suppression of indices of cortisol secretion by protein deprivation has been previously reported. ${ }^{27}$ Thus, the lowering of insulin levels on protein restriction might have been mediated by changes in cortisol secretion. The decrease in insulin levels with protein deprivation during treatment with cortisol argues against this possibility.

The plasma level of branched chain amino acids is elevated in obesity, ${ }^{28,29}$ probably as a consequence of diminished insulin action on muscle. Branched chain amino acids are believed to be capable of stimulating insulin release. On protein deprivation, there was a marked decrease in the plasma level of branched chain amino acids, and this decrease could have mediated the decrease in basal insulin levels. More definitive studies, in which patients are fed branched chain amino acids to restore the plasma levels of the amino acids to those of the control period during protein deprivation, have not been carried out.

The role of gastrointestinal hormones in the suppression of insulin levels during protein restriction has not been studied. It is known that somatostatin and gastric inhibitory polypeptide (GIP) play a role in nutrient absorption and nutrient-stimulated insulin secretion. ${ }^{30}$ Somatostatin secretion is deficient in obese hyperglycemic mice. ${ }^{31} \mathrm{~A}$ deficiency of somatostatin might explain the development of hyperinsulinemia in these animals. Hypersecretion of GIP has been observed $^{32}$ in obese subjects with normal glucose tolerance after ingestion of a mixed meal. This abnormality can be reversed by calorie restriction, suggesting that the hypersecretion of GIP is secondary to obesity and excessive food intake. Thus, protein deprivation could have decreased basal insulin levels by modifying the basal secretion of these gastrointestinal hormones.

The effect of protein deprivation on basal insulin levels in obesity differ from those observed in patients with protein calorie malnutrition (PCM). ${ }^{33.34}$ In the latter, basal insulin levels are the same during the state of malnutrition and following refeeding. The major abnormality in these patients is an impairment in early phase insulin release, accompanied by glucose intolerance. In contrast to our obese subjects, who were being fed weight-maintaining diets with high carbohydrate content, patients with PCM are on chronic caloric restriction and their potassium and metabolic substrates are probably depleted.

The results reported here on protein deprivation do not necessarily imply that a high protein intake is responsible for hyperinsulinemia in obesity. However, because of its well-known ability to stimulate insulin secretion, ${ }^{35}$ protein may indeed play a role in the pathogenesis of the hyperinsulinemia and insulin resistance found in obesity.

\section{REFERENCES}

1. Rabinowitz D: Some endocrine and metabolic aspects of obesity. Ann Rev Med 21:241, 1970

2. Karam JH, Grodsky GM, Forsham PH: Excessive insulin response to glucose in obese subjects as measured by immunochemical assay. J Am Diet Assoc 12:197, 1963

3. Grodsky GM, Benoit FL: Effect of massive weight reduction on insulin secretion in obese subjects, in Ostman J (ed): Diabetes, Proceedings, Sixth Congress of the International Diabetes Federation Amsterdam, Excerpta Medica, 1969, p 540

4. Jackson IMD, McKiddie MT, Buchanan KD: Effect of fasting on glucose and insulin metabolism of obese patients. Lancet $1: 285,1969$

5. Farrant PC, Neville RWJ, Stewart GA: Insulin release in response to oral glucose in obesity: The effect of reduction of body weight. Diabetologia 5:198-200, 1969

6. Sims EAH, Danforth E, Horton ES, et al: Endocrine and metabolic effects of experimental obesity in man. Recent Prog Horm Res 29:457, 1973
7. Grey N, Kipnis DM: Effect of diet composition on hyperinsulinemia of obesity. N Engl J Med 285:827 831, 1971

8. Bierman EL: Effect of carbohydrate rich diet on glucose tolerance and insulin secretion in diabetic subjects, Froesch ER, Yudkin J (eds): Sixth Capri Conference, Acta Diabetologica Latina, vol 9, suppl 1, 1972, p 377

9. Brunzell JD, Lerner RL, Hazzard WR, et al: Improved glucose tolerance with high carbohydrate feeding in mild diabetes. N Engl J Med 284:521, 1971

10. Morgan CR, Lazarow A: Immunoassay of insulin: Two antibody system. Plasma insulin levels of normal, subdiabetic and diabetic rats. Diabetes 12:115, 1963

11. Pek S, Fajans SS, Floyd JC Jr, et al: Failure of sulfonyl-ureas to suppress plasma glucagon in man. Diabetes $21: 216,1972$

12. Dash AJ, England BJ, Midgley AR, et al: Specific non-chromatographic radioimmunoassay for human plasma cortisol. Steroids 26:647, 1975 
13. Medzihradsky F, Dahlstrom PJ: A specific, low cost procedure for the automated determination of blood glucose. Univ Mich Med Ctr J 12:188, 1971

14. Silber CC, Porter RH: The determination of 17,21 dihydroxy-20-ketosteroids in urine and plasma. J Biol Chem 210:923, 1954

15. Drenick EJ, Brickman AS, Gold EM: Dissociation of the obesity-hyperinsulinemia relationship following dietary restriction and hyperalimentation. Am J Clin Nutr 25:746, 1972

16. Salans LB, Danforth E, Horton ES, et al: Dissociation of the effect of adiposity and diet on glucose, insulin and adipose tissue metabolism in human obesity. $J$ Clin Invest 51:84a, 1972

17. Laube H, Fussganger RD, Goberna R, et al: Zur bedentung einer isucalorischen stärke-oder rohrzckerreichen nahrung auf die insulinseckration und glucoseassimilation. Klin Wochenschr 50:239, 1972

18. Chick WL, Like AA: Effects of diet on pancreatic beta cell replication in mice with hereditary diabetes. Am J Physiol 221:202, 1971

19. Stern JS, Batchelor BR, Hollander N, et al: Adipose cell size and immunoreactive insulin levels in obese and normal weight adults. Lancet 2:948, 1972

20. Livingston JN, Cuatrecasas P, Lockwood DH: Insulin insensitivity of large fat cells. Science 177:626, 1972

21. Lockwood DH, Livingston JN, Amatruda JM: Relation of insulin receptors to insulin resistance. Fed Proc $34: 1564,1975$

22. Archer JA, Gorden P, Gavin JR, et al: Insulin receptors in human circulating lymphocytes: Application to the study of insulin resistance in man. J Clin Endocrinol Metab 36:627, 1973

23. DeMeyts P, Roth J, Neville DM, et al: Insulin interaction with its receptors: Experimental evidence for negative cooperativity. Biochem Biophys Res Commun 55:154, 1973

24. Gavin JR III, Roth J, Neville DM Jr, et al: Insulin dependent regulation of insulin receptor concentrations: A direct demonstration in cell culture. Proc Natl Acad Sci USA 71:84, 1974

25. Schteingart DE, Gregerman RI, Conn JW: A comparison of the characteristics of increased adrenal cortical function in obesity and Cushing's syndrome. Metabolism 12:484, 1963

26. Vague PH, Boeuf G, Depieds R, et al: Plasma insulin levels in human obesity, in Vague $\mathrm{J}$ (ed): Physiopathology of Adipose Tissue. Amsterdam, Excerpta Medica, 1969, p 203

27. Schteingart DE, Conn JW: Dietary protein and corticosteroid secretion, in Froesch ER, Yudkin J (eds): Sixth Capri Conference Acta Diabetologica Latina, vol 9, suppl 1, 1972 p 328

28. Felig P, Marliss E, Cahill GF: Plasma amino acid levels and insulin secretion in obesity. $N$ Engl J Med 281:811-816, 1969

29. Felig P, Marliss E, Cahill GF: The plasma amino acid levels are elevated in obesity. $N$ Engl J Med 282:166, 1970

30. Dupré J: The enteroinsular axis, in Bloom SR (ed): Gut Hormones. New York, Churchill, Livingstone, 1978, 303-309

31. Patel $\mathrm{Y}$, Weir A, Bankier $\mathrm{L}$, et al: Changes in pancreatic somatostatin (SRIF) concentration in diabetes. (Abstract \#832). Program of the Fifth International Congress of Endocrinology, Hamburg, Germany, July 1824, 1976, p 343

32. Ebert R, Willms B, Brown JC, et al: Serum gastric inhibitory polypeptide levels in obese subjects and after weight reduction. Eur J Clin Invest 6:327, 1976 (abstract)

33. Smith SR, Edgar PJ, Pozefsky T, et al: Insulin secretion and glucose tolerance in adults with protein calorie malnutrition. Metabolism 24:1073, 1975

34. Becher DJ, Mann MD, Weinkove E, et al: Early insulin release and its response to potassium supplementation in protein-calorie malnutrition. Diabetologia 11:237, 1975

35. Floyd JC, Fajans SS, Knopf RF, et al: Influence of proteins on insulin secretion, in Froesch ER, Yudkin J (eds): Sixth Capri Conference, Acta Diabetologica Latina, vol 9, suppl 1, 1972, p 302 